\title{
EXPERIMENTAL INVESTIGATION ON STRUCTURAL LIGHTWEIGHT CONCRETE BY PARTIAL REPLACEMENT OF COARSE AGGREGATE USING PUMICE AGGREGATE
}

\author{
M. Rajasekhar \\ Assistant professor, Department of Civil Engineering \\ St. Martin's Engineering College, Dhulapally, Hyderabad, Telangana, India \\ K. Venkataramana, S. Prashanth, L. Hari Krishna, K. Mahendra \\ JNTUH Student, Department of Civil Engineering \\ St. Martin's Engineering College, Dhulapally Hyderabad, Telangana, India.
}

\begin{abstract}
The project study with the special concrete such as light weight concrete by using pumice aggregate (natural aggregate). One of the vibrant disadvantages of nominal concrete having high dead load (self weight). This heavy self weight will make it to extent an uneconomical structural material. Light weight concrete having low density, reduction of dead load and to increase the thermal insulation. The reduction in density produced by using pumice aggregate as a limited replacement of coarse aggregate in concrete. In this investigation an attempt has been made to compare the nominal concrete and lightweight concrete using grade M20. Lightweight concrete is made of Partial replacement of Coarse Aggregate with different ratios of Pumice aggregate ranging from $0 \%, 15 \%, 30 \%$, and $45 \%$. This project is intensive to find out the compression strength and split tensile strength of lightweight concrete. The results are compared with conventional concrete to calculate the favourable replacement with the abovementioned replacements.
\end{abstract}

Keywords: Pumice aggregates, lightweight material, compressive.

\section{INTRODUCTION}

Structural light weight concrete is a most adaptable material in present developed construction. It has several advantages such as dead load lessening and thermal insulation is more. If walls and floorings are made with light weight concrete, it leads to economy of construction. The use of light weight concrete is gaining wide acceptance in building construction, obviously thanks to the considerable reduction in mass. Reduced dead load by using light weight aggregate results in reduction of earthquake damages to structures. The cement content may be a prominent think about the physical/mechanical and sturdiness properties of lightweight aggregate concretes. The ancient developments of lightweight concrete employed by Romans were Grecian and Italian pumice which were locally available lightweight aggregate. B Since that time there has been advanced in the production of lightweight concrete using either the natural lightweight aggregates such as pumice or the artificial lightweight aggregates. The need for the development of cheaper structures are further increased the demand for the utilization of lightweight concrete. (Devi Pravallika et al -2016).

Pumice is one among the foremost is feasible to commonly occurring natural lightweight coarse aggregates used for the assembly of concrete. Pumice lightweight aggregate is a volcanic-origin natural aggregate of very low specific gravity. The pumice is used to describe porous solids produced from the solidified magma produced during eruption of volcanoes. The voids are formed due to the release of gases in the magma. The resulting solids have a very high porous structure. Provided that pumice are often wont to produce structural grade lightweight concrete.

At the present time light weight concrete is usually used in precast and prestressed structures. Lightweight concrete offers the cost savings of plan adaptability and significant by giving less dead load, and improves the seismic structural response and fire rating much better, storey height is diminished, lesser foundation cost, and less reinforcing steel. (Lakshmi Kumar minapu, M K M V Ratnam, Dr. Rangaraju et al -2014)

\section{A). Objectives:}

-To determine whether pumice stone light weight concrete can be used as a structural concrete.

-To calculate the cube compressive strength and splittensile strength of light weight concrete having density below $1800 \mathrm{~kg} / \mathrm{m} 3$.

-To study the effect of various types replacements $(0 \%, 15 \%, 30 \%, 45 \%)$ of natural aggregate by light weight aggregate(pumice) and conventional concrete on 7, 28 days compressive strength.

-In order to decrease the self-weight of building. 


\section{International Journal of Engineering Applied Sciences and Technology, 2020 \\ Vol. 4, Issue 11, ISSN No. 2455-2143, Pages 429-433 \\ Published Online March 2020 in IJEAST (http://www.ijeast.com)}

\section{LITERATURE REVIEW}

A.Suba Lakshmi, et al (2017) Extreme value of strength is attained in 50\% replacement of Pumice. The light weight concrete has density $1500 \mathrm{~kg} / \mathrm{m}^{3}$ and conventional concrete $2400 \mathrm{~kg} / \mathrm{m}^{3}$. The increasing percentage of pumice stone will decrease strength of concrete (strength decreases).

K. Guru Kesav Kumar, et al (2016) M20, M25 and M30 grade of concrete used with replacement percentage $10 \%$ and $20 \%$ can be effectively used for structural purpose. Replacement of $30 \%$ can only be used for nonstructural purpose and optimum strength of replacement for $20 \%$ is effective.

B. Devi Pravallika, et al (2016) for the most part Pumice stone ingests more water contrasted with the ostensible coarse total to beat this issue extra utilization of super plasticizes is included. For substitution of $20 \%$ of pumice stone gives ideal incentive past $20 \%$ the compressive quality esteem diminishes.

Rajeswari S, et al (2016) with a replacement of $60 \%$ of pumice with coarse aggregate we can obtain maximum strength.

R. Kalpana, et al (2015) when the pumice content increases then flexural strength will be decreased. The spilt tensile strength of concrete drops with the increase in pumice percentage.

Lakshmi Kumar Minapu, et al (2014) with a replacement of coarse aggregate by pumice aggregate with varying percentage, the density decreases with increase in percentage of pumice aggregate. $20 \%$ of replacement gives the promising results.

U Rangaraju et al., (2014) studied the Properties of a light weight aggregate (pumice) and mineral admixtures (ash and Silica Fume). According to them results light weight concrete is not suitable for any construction work due to its overall strength \& weight reduction different trails.

\section{MATERIALS \& METHODOLOGY}

\section{A). Materials.}

a). Cement.

Ordinary Portland cement (OPC 53) was used in this investigation. The cement physical properties are tested in the laboratory as per IS: 12269-1999 code

Table-1: cement properties

\begin{tabular}{|c|l|c|}
\hline S.No. & \multicolumn{1}{|c|}{ Parameter } & Result \\
\hline 1 & Normal consistency test & $30 \%$ \\
\hline 2 & Fineness of cement & $4.8 \%$ \\
\hline 3 & Specific gravity of cement & 3.14 \\
\hline 4 & setting time (Initial) & $44 \mathrm{~min}$ \\
\hline 5 & setting time (Final) & $600 \mathrm{~min}$ \\
\hline 6 & Soundness of cement & $6 \mathrm{~mm}$ \\
\hline
\end{tabular}

\section{b). Fine Aggregate.}

Locally available sand is used in this concrete mix as the fine aggregate confirming to zone - II. specific gravity of fine aggregate is 2.64 .

\section{c). Coarse Aggregate.}

Coarse aggregate $20 \mathrm{~mm}$ size was used for this investigation, aggregate taken from the local quarry confirming to IS: $383: 1970$. The aggregate specific gravity is 2.66 .

\section{d). Pumice}

(Shivalinga Rao N et al - 2013) In this investigation we used pumice aggregate of $10 \mathrm{~mm}$ size. And 0.85 is the specific gravity of pumice. It is easily available natural light in weight aggregate which is formed during eruption of viscous magma. Pumice concrete have low thermal conductivity, and mixing of pumice concrete is very complicated compare to normal concrete.

\section{e). Water}

Water plays a vital role in preparation of concrete and potable water is used in this investigation.

\section{B). Methodology}

\section{a). Mix Design}

The mix design adopted to obtain M20 grade concrete is in accordance with IS: 10262 - 2009. The mix proportion obtained for nominal M20 grade is 1: 1.72: 2.83 with a w/c ratio of 0.50 . (Shivalinga Rao N - 2013)

\section{b). Mix proportion}

Coarse aggregate was partially replaced by pumice aggregate in the range of varying $15 \%, 30 \%$, and $45 \%$. And the mix proportions have been recommended based on trial mixes. In the present study, M20 grade with design mix as per IS: 456-2000 was used.

Table - 2: Mix proportion of different $\%$ of pumice aggregate.

\begin{tabular}{|c|c|c|c|c|c|}
\hline $\begin{array}{c}\text { Pumic } \\
\text { e } \%\end{array}$ & $\begin{array}{c}\text { Ceme } \\
\mathrm{nt} \mathrm{in} \\
\mathrm{kg} / \mathrm{m}^{3}\end{array}$ & $\begin{array}{c}\text { Fine } \\
\text { aggregat } \\
\text { e in } \\
\mathrm{kg} / \mathrm{m}^{3}\end{array}$ & $\begin{array}{c}\text { Coarse } \\
\text { aggregat } \\
\text { e in } \\
\mathrm{kg} / \mathrm{m}^{3}\end{array}$ & $\begin{array}{c}\text { Pumic } \\
\text { e in } \\
\mathrm{kg} / \mathrm{m}^{3}\end{array}$ & $\begin{array}{c}\text { Wate } \\
\mathrm{r} \text { in } \\
\text { lit/m } \\
3\end{array}$ \\
\hline $0 \%$ & 394.32 & 680.16 & 1118.15 & 0 & 197 \\
\hline $15 \%$ & 394.32 & 680.16 & 950.43 & 53.59 & 197 \\
\hline $45 \%$ & 394.32 & 680.16 & 782.70 & $\begin{array}{c}107.1 \\
9\end{array}$ & 197 \\
\hline
\end{tabular}




\section{International Journal of Engineering Applied Sciences and Technology, 2020 \\ Vol. 4, Issue 11, ISSN No. 2455-2143, Pages 429-433 \\ Published Online March 2020 in IJEAST (http://www.ijeast.com)}

\section{C). Experimental Procedure:}

In the present experimental investigation pumice aggregate has been used as partial replacement of coarse aggregate in concrete mixes. On replacing coarse aggregate with different percentage of pumice aggregate of $0 \%, 15 \%, 30 \% \& 45 \%$. The compressive strength and split tensile strength is studied at different ages of concrete cured in normal water.

\section{a). Casting}

The specimens are casted in the ratio of $0 \%, 15 \%, 30 \%$, $45 \%$, replacement of pumice aggregate respectively with each ratio comprising of 6 cubes and 6 cylinders. A total of 24 cubes and 24 cylinders were casted. After the casting process, the cubes and cylinders were kept for 24 hours and demoulded, and cured for 7 days and 28 days.

Table-3. Details of specimen

\begin{tabular}{|l|l|l|}
\hline $\begin{array}{l}\text { Properties } \\
\text { Studied }\end{array}$ & $\begin{array}{l}\text { Specim } \\
\text { en }\end{array}$ & Specimen Size(mm) \\
\hline $\begin{array}{l}\text { Compressive } \\
\text { strength }\end{array}$ & cube & 150 X 150 X 150 \\
\hline $\begin{array}{l}\text { Split tensile } \\
\text { strength }\end{array}$ & $\begin{array}{l}\text { cylinde } \\
\mathrm{r}\end{array}$ & 300 height \& 150 dia \\
\hline
\end{tabular}

\section{TEST RESULTS}

\section{A). Compression strength results}

(Muralitharan R.S. et al., - 2015). The cubes of standard size $150 \times 150 \times 150 \mathrm{~mm}$ are used to find the compression strength of concrete. The load at the failure is noted down and compressive strength was calculated. Load at the let down of cube divided by area of specimen gives the compression strength of the concrete. The compression strengths of the casted specimens were determined by the compression test machine and are tabulated as follows.

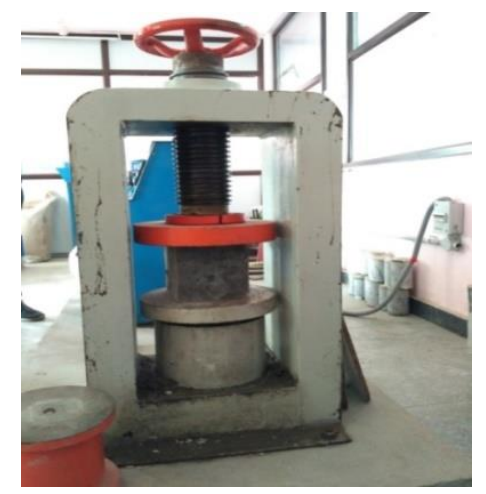

Fig-1: testing of cube specimen
Table -4 : compression strength results for 7 days \& 28 days

\begin{tabular}{|c|c|c|c|}
\hline \multirow{2}{*}{$\begin{array}{c}\text { S.N } \\
\mathbf{O}\end{array}$} & \multirow{2}{*}{$\begin{array}{c}\text { Percentage } \\
\text { of } \\
\text { Replacemen } \\
\text { t (pumice) }\end{array}$} & \multicolumn{2}{|c|}{$\begin{array}{l}\text { Average compression strength } \\
\text { in } \mathrm{N} / \mathrm{mm}^{2}\end{array}$} \\
\hline & & 7days & 28days \\
\hline 1 & $0 \%$ & 19.10 & 31 \\
\hline 2 & $15 \%$ & 23.92 & 36.75 \\
\hline 3 & $30 \%$ & 21.31 & 33.95 \\
\hline 4 & $45 \%$ & 18.2 & 27.52 \\
\hline
\end{tabular}

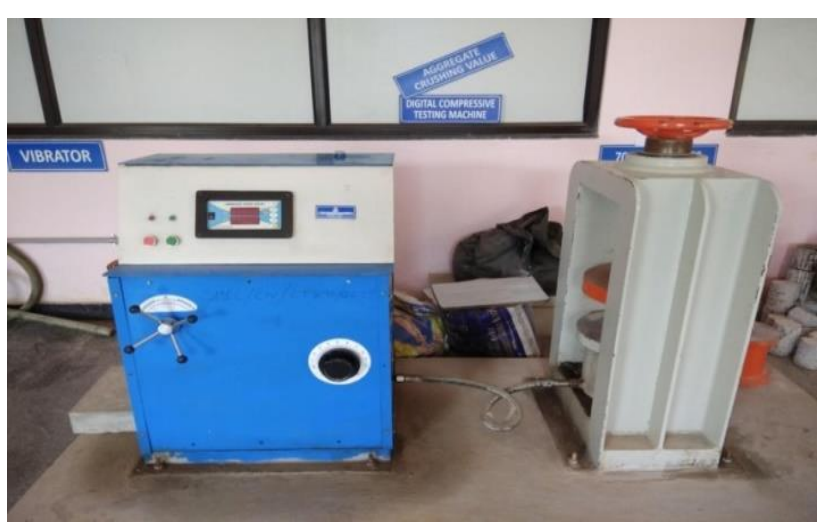

Fig-2: Compression test machine

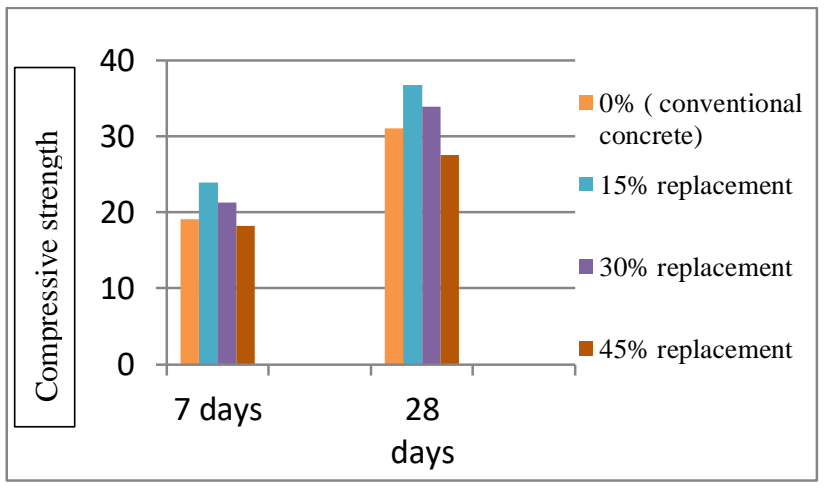

Graph-1: comparison of compressive strength results

\section{B). Split - tensile strength results.}

Cylinder specimen of size $150 \mathrm{~mm}$ dia and $300 \mathrm{~mm}$ length were casted with pumice aggregate as limited replacement of coarse aggregate. after casting, the cylinders must be vibrated using a table vibrator. After 24 hours of the casting the specimens were demoulded and subjected to curing for 7 days, \&28 days in portable water. After that specimens should be tested using universal testing machine of $2000 \mathrm{kN}$ capacity. 

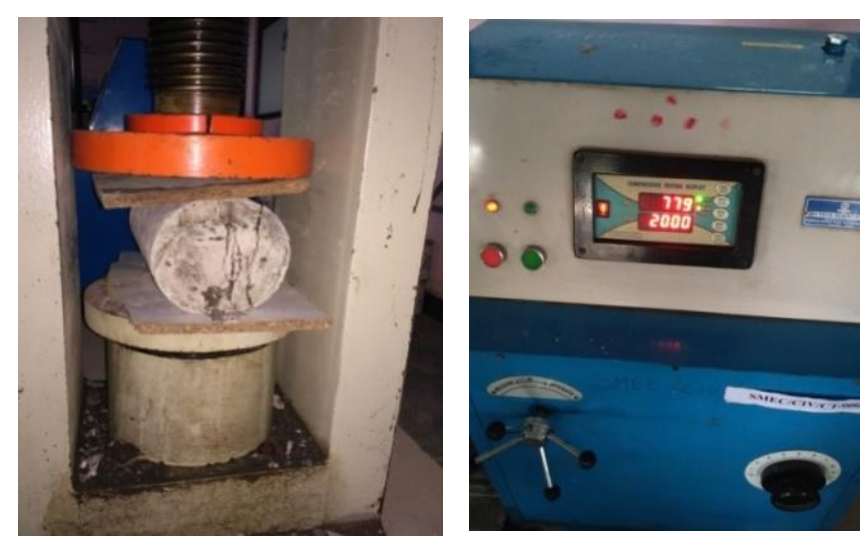

Fig-3: Testing of cylinders

Table -5 : split-tensile strength results (7days \& 28 days)

\begin{tabular}{|c|c|c|c|}
\hline \multirow{2}{*}{$\begin{array}{l}\text { S.N } \\
\mathbf{O}\end{array}$} & \multirow{2}{*}{$\begin{array}{c}\text { Percentage } \\
\text { of } \\
\text { Replacement } \\
\text { (pumice) }\end{array}$} & \multicolumn{2}{|c|}{$\begin{array}{l}\text { Average split-tensile strength } \\
\left(\mathrm{N} / \mathrm{mm}^{2}\right)\end{array}$} \\
\hline & & 7 days & 28 days \\
\hline 1 & $0 \%$ & 2.67 & 4.22 \\
\hline 2 & $15 \%$ & 2.98 & 5.17 \\
\hline 3 & $30 \%$ & 2.68 & 4.69 \\
\hline 4 & $45 \%$ & 2.31 & 3.39 \\
\hline
\end{tabular}

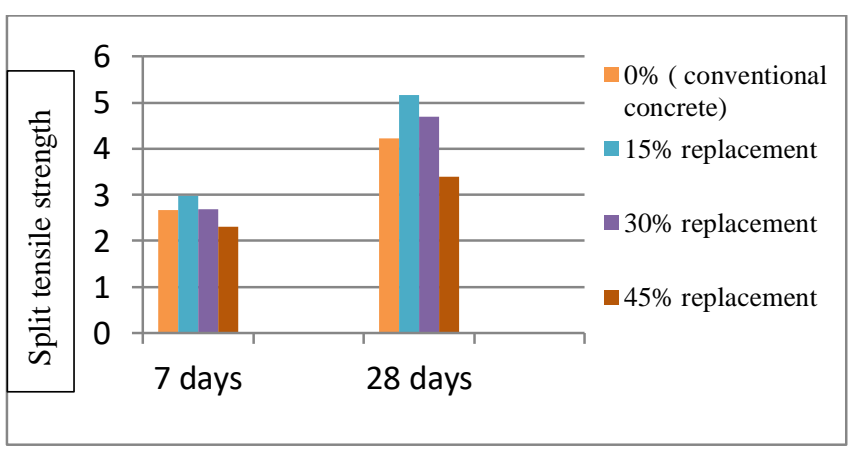

Graph-2: comparison of split tensile strength results

\section{C). Concrete Density}

Table - 6 : density of concrete for each ratio

\begin{tabular}{|c|c|c|}
\hline S.NO. & $\begin{array}{c}\text { Percentage of } \\
\text { Replacement (pumice) }\end{array}$ & $\begin{array}{c}\text { Density of } \\
\text { Concrete } \\
\text { (Kg/m3) }\end{array}$ \\
\hline 1 & $0 \%$ & 2466.7 \\
\hline 2 & $15 \%$ & 2298.4 \\
\hline 3 & $30 \%$ & 2050.4 \\
\hline 4 & $45 \%$ & 1828.0 \\
\hline
\end{tabular}

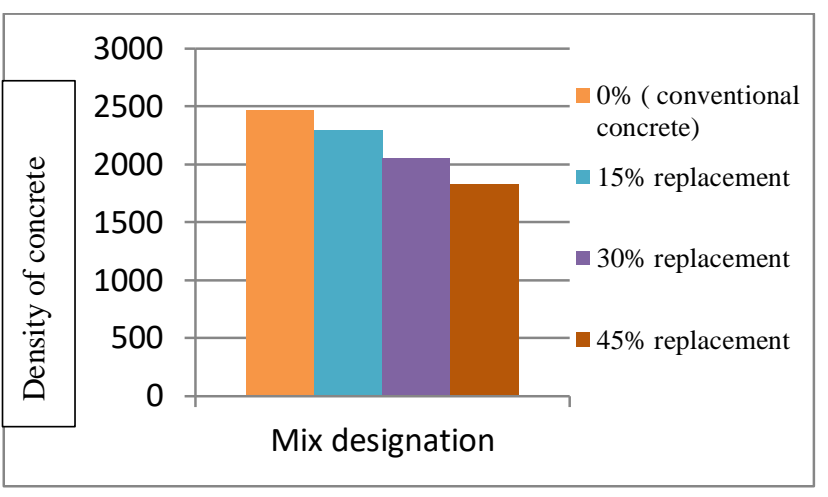

Graph- 3: comparison of density of concrete

\section{CONCLUSIONS}

Based on the experimental study and the results found from the study, following conclusions are made.

- The density of concrete is very much reduced as compared to nominal concrete so the self-weight of structure is also reduced. Concrete density was decreases as we increase the replacement percentage of normal coarse aggregate with pumice aggregate.

- By replacing $15 \%$ and $30 \%$ of normal aggregate with pumice aggregate the compressive strength is Promising. And gives better results compare to nominal concrete.

- The $45 \%$ replacement of coarse aggregate with pumice aggregate gives least compressive strength with more reduction in weight of concrete. After analysing the results of $45 \%$ replacement we conclude that $45 \%$ replacement effectively used for non-structural purpose only.

- Henceforth $15 \%$ and $30 \%$ of replacement can be effectively used for structural purpose.

\section{REFERENCES}

[1] Praveen Kumar M., Dr. Rajasekhar (2016) "An Experimental study on light weight concrete by partial replacement of coarse aggregate by pumice stone and cement by ggbs" ijsrd,vol4,issues 09. (Page no:634-640)

[2] Sivalinga Rao N., Radha Ratna Kumari Y., (2013) "Study on Fiber Reinforced Light Weight Aggregate (Natural Pumice Stone) Concrete." IJSER.

[3] Guru Kesav Kumar K., Krishnaveni C. (2016 ) "Study on Replacement of aggregate with Pumice Stone in Cement Concrete" the IJEST, page no -113

[4] Devi Pravallika B., Venkateswara Rao K. (2016 )"The investigation on Properties of Lightweight Concrete using Lightweight Aggregate" IJSR, Volume 5 Issue 6.

[5] Dr. sunilaa George, (2016) "the investigation of light weight concrete by partial replacement of 
coarse aggregate using pumice aggregate" (page no-.50. )

[6] Gowthama prasanth.U1, Jeyaraj.C2, (2016) "Experimental Investigation of Floating slab with Incorporated Pumice stone and Vermiculite" IJIRT, volume 3, issue 5, (page no-.223),

[7] IS -456-2000. Plain and reinforced concrete, bureau of Indian standards.

[8] Mix design IS: 10262:2009

[9] Muralitharan R.S. et al., ( 2015) Basic Properties of Pumice Aggregate; IJESE Volume 08, No.04, Page no- 256-258

[10] Parhizkar T., Najimi M. and Pourkhorshidi A.R., (2012) "Application of pumice aggregate in structural lightweight concrete", Asian journal of civil engineering Page no- 43-54.

[11] Weigler, H. and Karl, S. Stahlleichtbeton, Bauverlag GMBH, Wiesbaden and Berlin,( 1972) Page no - 38-43.

[12] Dr. Bhaskar Desai, Sathyam A.,(2014) "Some Studies on Strength properties of Light Weight Cinder Aggregate Concrete", IJSR , Volume 4, Issue 2, 1 ISSN 2250-3153.

[13] Lakshmi Kumar minapu, M K M V Ratnam, Dr. Rangaraju (2014) "Experimental study on light weight aggregate concrete with pumice stone, silica fume and fly ash as a partial replacement of coarse aggregate".

[14] Ashworth T., Ashworth E., (1992) written an article on the ASTM journal Insulation Materials: Testing and Applications, Euro code No. 2 Part $1-4$ : , "The Use of Lightweight Aggregate Concrete with Closed Structure". 